\title{
JUURNAL_RU
}

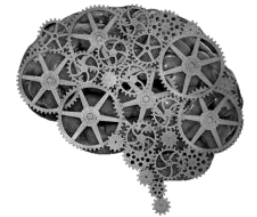

COMPANY GROUP "INTELLEKT"

Егорова С. П. МГСУ

Москва, Россия

doi: 10.18411/lj2016-5-1-05

\section{Значение цветовой гаммы фасадов жилых домов в формировании городской застройки}

Научный руководитель -профессор МГСУ Щербина Е.В.

Концепция устойчивого развития «sustainable development» города, предполагающая создание безопасной и качественной среды обитания, удовлетворяющей запросам развития современного человеческого сообщества, при этом, не ущемляя возможности будущих поколений человечества, должна находится в основе принятия градостроительных и архитектурных решений. Критериями для оценки принятых решений становятся такие понятия, как качество, функциональность, доступность, ресурсо-эффективность, биосовместимость, социальная ориентированность, технологичность, конкурентоспособность [1]. В современном городе для создания жилой застройки широко применяется технология строительства домов с использованием сборных элементов, что позволяет сократить сроки строительства и обеспечить необходимое качество жилого фонда. На территориях с высокой градостроительной ценностью земель, ведется строительство домов по индивидуальным проектам. Следует отметить, что для оценки проектных решений, перечисленные выше критерии, практически не учитывают цветовую гамму фасадов, которая определяется домостроительными комбинатами и архитекторами по своим критериям, часто ориентированным на 
сокращение стоимости продукции. Следует отметить и то, что в современной практике недостаточно используется исторический опыт и архитектурные традиции. Кроме того, практически отсутствуют исследования, посвященные выявлению цветовых предпочтений рядовых жителей.

Однако цвет играет важную роль в формировании облика городской среды. Он не только усиливает восприятие архитектурных форм, но и оказывает значительное психологическое воздействие на жителей города, как социальной составляющей модели устойчивого развития, которая предполагает сбалансированное состояние трех основных составляющих системы городской среды: социально-экономической, экологической и техногенной. Проблемы цветовосприятия человеком городской среды, колористики городской застройки поднимались неоднократно в работах как отечественных, так и зарубежных авторов [2,-4,7-9]. Их анализ позволяет выделить основные факторы цветового воздействия:

- Психология и физиология восприятия цвета человеком, особенно изменение восприятия человеком цвета при различной освещенности [3]. Сегодня это имеет большое значение, так как фасадные плоскости имеют разное положение по отношению к направлению солнечных лучей, естественное освещение различается по интенсивности и цветовому спектру в разное время суток и года, в темное время суток в жилых районах присутствует искусственное освещение.

- Отношение между цветовой реальностью и цветовым воздействием в создании художественного образа жилой среды: между тем, что воспринимается глазом и тем, что отражается в сознании человека. Здесь возникают проблемы субъективного восприятия цвета.

- Традиции цветовой гаммы и климатические особенности, которые всегда находят отражение в жилой архитектуре.

- Возрастные предпочтения цветов, прослеживаются следующие тенденции: молодежь больше тяготеет к ярким открытым цветам, 
старшее поколение отдает предпочтение традиционной «классической» гамме, характерной для исторической застройки.

Цветовая картина города постоянно меняется. Москва, в этом случае, не является исключением. Существенным является отличие застройки центральной исторической части города от спальных районов, расположенных на периферии. Здесь можно выделить различные проблемы, ведущие к формированию некомфортной, а подчас и агрессивной среды, что отмечают и сами жители.

В центральных районах в основном преобладает историческая застройка с традиционной цветовой палитрой, приближенной к гармоничным природным оттенкам. Также отмечается обилие зелени. Гармонию городской среды здесь нарушают многочисленные стенды, вывески, рекламы, плакаты, зачастую имеющие несоразмерный среде масштаб, агрессивное цветовое решение, создающее режущую глаз пестроту. Либо встречаются современные инородные включения, нарушающие целостное восприятие среды.

В спальных районах проблемой становится безликая однообразная бесцветная застройка, представленная панельными домами типовых серий. Монотонность застройки этих территорий создает депрессивную атмосферу, затрудняет ориентацию в пространстве жилого района. В настоящее время в Москве значительное внимание уделяется разнообразию цветовых решений фасадов, что стало возможно благодаря внедрению новых технологий использование цветного бетона. В этом случае повышается эстетическое качество фасадов зданий при сохранении экономической целесообразности решений, нет необходимости тратить дополнительные средства на финальную отделку фасадов [5]. Проведенные исследования показали значимость цветосветовой композиции в формировании жилой застройки для создания комфортной среды проживания, и выделить для её решения следующие задачи:

- выявить особенности восприятия человеком цвето-композиционных решений жилых зданий в жилой застройке; 
- определить существующие вкусовые тенденции по предпочтительности определенных цвето-композиционных решений у жителей города.

Для решения поставленных задач наиболее целесообразным является метод анкетирования или опроса населения, который наиболее применим к решению социальных задач [10].

Разработанная нами анкета включала в себя три смысловых блока:

1. Социально-демографические характеристики респондента: пол, возраст;

2. Индивидуальные цветовые предпочтения респондента в целом и по отношению к выбору цвета фасада своего жилого дома;

3. Индивидуальное восприятие колористических решений отдельных зданий в жилой застройке.

Анкетирование проводится с использованием интернет, анкета размещена на

https://docs.google.com/forms/d/1lpEtaWVflQzlskvnu1IGPnXxfMq7jN7A_BPwIq8ql ww/viewform?c=0\&w=1\&usp=mail_form_link . На сегодня в опросе приняли участие 46 человек. Обработка результатов показывает, что только 10\% участников не «обращают внимание» на цвет фасадов, что свидетельствует о значимости поставленной задачи.

\section{Выводы}

1. Цветовая композиция застройки играет важную роль в формировании облика городской среды, и служит важным фактором реализации концепции устойчивого развития.

2. Для реализации поставленных задач метод анкетирования позволяет получить достоверные и обоснованные данные, необходимые для формирования цветовой композиции фасадов домов жилых районов, оказывающей положительное психологическое воздействие на жителей города 


\section{Литература:}

1. Щербина Е.В., Данилина Н.В. Градостроительные аспекты проектирования устойчивой городской среды, Вестник ИрГТУ, 2014, № 11, c. $183-186$.

2. Sherbina E.V., Danilina N.V. Vlasov D.N. City planning issues for sustainable development /International Journal of Applied Engineering Research ISSN 0973-4562 Volume 10, Number 22 (2015), pp 43131-43138 (c) Research India Publications. http://www.ripublication.com.

3. Алиева Н.З. Физика цвета и психология зрительного восприятия: учеб. пособие для студ. высш. учебн. заведений / Н.З. Алиева. - М.: Издательский центр «Академия», 2008. - 208 с.

4. Потокина Т.М. Понятие цвета и его роль в архитектуре // Вестник Волгоградского государственного университета. Серия 7: Философия. Социология и социальные технологии. - Выпуск № 1 / 2009. - С. 77-79.

5. Волкова Н.Ю. Формирование цвето-композиционных решений фасадов жилых домов и комплексов. - Автореф. дис. ... канд. арх.:18.00.02. - М., 2009. - 26 c.

6. Все о новых сериях панельных домов // Новостройки Москвы и Московской области. - [Электронный ресурс]. - Режим доступа: http://www.msknovostroy.ru/article/na-zametku/novye-serii-panelnyhdomov.html.

7. Ефимов А.В. Колористика города. - М.: Стройиздат, 1990. - 272 с.

8. Ефимов А.В. Формообразующее действие полихромии в архитектуре. М. Стройиздат, 1984. - 168 с.

9. Михалчева С.Г. Архитектурное цветоведение. Проектирование цветовой среды улицы в исторической части города: учебное пособие [Текст] / С.Г. Михалчева - Пенза: кафедра Градостроительство ПГУАС, 2015. - 155 с.

10. Щербина Е.В., Горбенкова Е.В. Значение социально-демографических факторов для устойчивого развития агрогородков// Научное обозрение, 2013, № 9. С 128-131 